\title{
Aplikasi Eletronik Manajemen Keuangan DIPA pada Lembaga Pendidikan Islam Negeri di Tengah Pandemi Covid-19 Sebagai Upaya WFH
}

\author{
Ali Marzuki Zebua \\ Dosen Manajemen Pendidikan Islam IAIN Kerinci \\ alimarzukizebua@iainkerinci.ac.id
}

\begin{abstract}
Abstrak
Tidak dapat di elakkan bahwa pengaruh muncul dan menyebarnya pandemi Covid-19 sangat memengaruhi seluruh sendi kehidupan, tidak terkecuali dalam dunia pendidikan. Keadaan ini pada akhirnya memancing respon dari para pemangku kepentingan dan pemangku kebijakan pendidikan dengan mengubah proses serta prosedur kegiatan di dalam pendidikan. Semua kegiatan perkantoran dan penatausahaan/administrasi di dalam pendidikan dilakukan secara online. Pada sisi yang lain, lembaga pendidikan juga dituntut untuk dapat memberikan pelayanan standar kesehatan melalui WFH. Pada tulisan ini, penulis menyoroti bagaimana sistem aplikasi online manajemen keuangan DIPA pada lembaga pendidikan Islam Negeri di tengah pandemi Covid-19 dijalankan secara efektif dan efisien sebagai bentuk upaya bekerja dari rumah (Work From Home). Kebijakan dalam pengelolaan keuangan pada saat pandemi ini melalui aplikasi e-SPM dalam penerapan prinsip accounting dan e-Rekon dalam penerapan prinsip auditing. Aplikasi ini sangat efektif dalam menerapkan protokol kesehatan social distancing. Efek dari hal ini juga akan efisiennya penghematan anggaran perjalanan dinas lembaga pendidikan Islam Negeri. Kegunaan dari tulisan ini sebagai bentuk informasi bagi stakeholder pendidikan yang mungkin belum banyak mengetahui aplikasi-aplikasi di dalam pengelolaan keuangan pendidikan Negeri.
\end{abstract}

Kata Kunci : Covid-19, e-SPM, e-Rekon, DIPA, Pengelolaan Keuangan Pendidikan

\begin{abstract}
:
It is inevitable that the influence of the emergence and spread of the Covid-19 pandemic has greatly affected all aspects of life, including in the world of education. This condition ultimately provokes a response from stakeholders and education policymakers by changing the processes and procedures for activities in education. All office and administration activities in education are carried out online. On the other hand, educational institutions are also required to be able to provide standard health services through WFH. In this paper, the author is interested in how the DIPA online financial management application system at State Islamic education institutions in the midst of the Covid-19 pandemic is carried out
\end{abstract}


effectively and efficiently as a form of an effort to work from home (Work From Home ). Policies in financial management during this pandemic are through e-SPM application in applying accounting principles and e-Rekon in applying audit principles. This app is very effective in implementing social distancing health protocols. The effect of this will also be the efficiency of the official travel budgets of State Islamic education institutions. The usefulness of this paper is a form of information for education stakeholders who may not have seen many applications in the management of public education finance.

Keywords : Covid-19, e-SPM, e-Rekon, DIPA, Educational Financial Management

\section{Pendahuluan}

Dari sekian banyak komponen-komponen dasar pendidikan, hal yang dianggap penting adalah uang dan pembiayaan. Uang dipandang sebagai darah dalam sebuah organisasi dalam meningkatkan mutu pendidikan dan mutu SDM itu sendiri. Tetapi ada juga yang berpendapat bahwa uang ibarat kuda dalam organisasi. Organisasi diibaratkan sebagai gerobak. Pedati tidak berjalan tanpa ditarik dengan kuda. Pendidikan tidak berjalan tanpa adanya biaya atau anggaran. Dengan demikian, faktor penting yang menjadi mutu pendidikan dan jalannya fungsi pendidikan SDM yakni biaya pendidikan ${ }^{1}$.

Kita tidak dapat menutup mata dan telinga akan dampak anggaran Negara terhadap pendidikan kita yang dipangkas di masa pandemi Coronavirus Disease 2019 (Covid-19) ini. Banyak lembaga pendidikan mengalami defisit, tidak terkecuali lembaga pendidikan negeri milik pemerintah. Di Kementerian Pendidikan dan Kebudayaan (Kemendikbud) misalnya, pemangkasan anggaran untuk penanganan pandemi Covid-19 sebesar 5 Triliun. Sementara di Kementerian Agama, anggaran dipangkas sebesar 2,6 Triliun. Anggaran ini menyebabkan terhambatnya program bagian Dirjen Pendidikan Islam. Kemenag memotong Uang Kuliah Tunggal (UKT) mahasiswa di Perguruan Tinggi dan dan SPP siswa di madrasah yang program ini semata untuk mengurangi beban biaya pendidikan.

Dampak dari pemangkasan anggaran ini berdampak pada lembaga pendidikan negeri sehingga aggaran DIPA-nya (Daftar Isian Pelaksanaan Anggaran) mengalami pengurangan. Pemangkasan itu dialihkan kepada kegiatan kesehatan untuk menangani

\footnotetext{
1 Akdon et al., Manajemen Pembiayaan Pendidikan, ed. Pipih Latifah (Bandung: Remaja Rosdakarya, 2015), 266.
} 
pandemi Covid-19 ini. Begitupun dengan lembaga pendidikan swasta. Cash flow pendidikan swasta mengalami penurunan sehingga pendapatan lembaga pendidikan swasta mengalami ancaman.

Turunnya pendapatan lembaga pendidikan swasta ini dikarenakan banyaknya para orang tua atau wali murid mengalami pemangkasan gaji di tempat kerjanya, bahkan ada yang mengalami pemutusan hubungan kerja (PHK) sehingga berdampak pada mandetnya pembayaran uang pendidikan bulanan atau semester anaknya, padahal pendapatan terbesar dari lembaga pendidikan swasta adalah dari uang bulanan dari para murid-muridnya. Macetnya pembayaran uang pendidikan bulanan atau semester ini menyebabkan para pengelola lembaga tersebut tidak mampu menggaji para guru/dosen dan stafnya, bahkan ada lembaga pendidikan yang mengambil tindakan PHK terhadap para guru/dosen dan stafnya tersebut.

Namun pemerintah melihat hal ini tidak tinggal diam. Sekolah/madrasah swasta misalnya, pemerintah memberikan bantuan melalui Bantuan Operasional Sekolah (BOS) Afirmasi dan BOS Kinerja. BOS Afirmasi dan BOS Kinerja ini difokuskan pada sekolah/madrasah yang paling membutuhkan dan terdampak pandemi Covid-19. Dengan ketentuan sekolah/madrasah negeri dan swasta yang paling membutuhkan dana bantuan tersebut sebesar Rp. 60 juta per sekolah per tahun. Dana tersebut disalurkan langsung dari Kementerian Keuangan ke rekening sekolah/madrasah.

BOS Afirmasi dan BOS kinerja ini bisa digunakan untuk kegiatan yang sama dengan BOS Reguler selama masa pandemi Covid-19. Penggunaan dana BOS tersebut dapat digunakan untuk belanja barang kebutuhan siswa di rumah seperti belanja pembelian pulsa, paket data internet, layanan pendidikan daring berbayar, pembayaran gaji tenaga guru dan staf jika mencukupi, sampai dengan belanja kebutuhan kebersihan terkait pencegahan Covid-19.

Sekolah/madrasah yang mendapat dana BOS Afirmasi ${ }^{2}$ tersebut memiliki kriteria khusus. Pertama, sekolah/madrasah yang berada di wilayah terpencil dan atau terbelakang atau berada pada daerah perbatasan antar Negara. Kedua, dikhususkan bagi sekolah/madrasah dengan proporsi siswa dari keluarga miskin yang lebih besar,

2 Peraturan Menteri Pendidikan dan Kebudayaan (Permendikbud) Nomor 24 Tahun 2020 tentang Petunjuk Teknis Bantuan Operasional Sekolah (BOS) Afirmasi dan Bantuan Operasional Sekolah (BOS) Kinerja, dana BOS Afirmasi, 2020. 
sekolah/madrasah yang menerima dana BOS Regulernya lebih rendah, dan sekolah/madrasah yang memiliki proporsi guru tidak tetap lebih besar.

Terkait dengan hal di atas, lembaga pendidikan tidak hanya berpangku tangan menerima bantuan dana dari pemerintah tersebut. Lembaga pendidikan di masa ini harus lebih survive menyelaraskan organisasi dan melindungi aset mereka agar tetap aman. Jika lembaga pendidikan kita tidak dapat survive maka cerita pembahasan perubahan pola kerja seperti pengaturan Work From Home (WFH) kemudian menjadi seakan tidak berguna.

Madrasah Negeri yang pengelolaan anggaran DIPA-nya diberi otonomi langsung oleh pemerintah, sampai saat ini terlihat lancar-lancar saja dalam mencairkan anggaran kegiatannya, namun untuk sekolah-sekolah negeri umum misalnya, hal tersebut malah mengalami penyendatan pencairan anggaran. Hal ini menjadi kelebihan bagi Madrasah Negeri dalam memaksimalkan penyerapan anggaran dan lebih flesibel dalam pencairan anggarannya. Contoh saja seperti pencairan dana sertifikasi guru yang dilakukan rutin tiap bulan, berbeda dengan sekolah negeri umum yang pencairannya bisa sampai tiga bulan sekali karena pencairan anggarannya langsung dari provinsi. Ditambah lagi pada masa pandemi Covid-19 ini, intensitas pengusulan Surat Perintah Membayar (SPM) anggaran kegiatan lembaga dibatasi oleh Kantor Pelayanan Perbendaharaan Negara (KPPN) sebagai Bendahara Umum Negara (BUN), menyebabkan sekolah umum mengalami hambatan dalam kegiatan angagrannya. Ini menjadi kelebihan bagi madrasah negeri dalam mengelola anggaran pendidikannya.

Sebagai upaya dalam menjaga jarak (social distancing) dalam penanganan pandemi Covid-19, pihak KPPN melalui Kementerian Keuangannya (Kemenkeu) menerapkan pencairan angaran melalui system online. Dahulu sebelum adanya pandemi Covid-19, pengusulan SPM dilakukan secara manual di KPPN. Namun pada masa pandemi Covid-19 ini SPM diusulkan melalui system online. Terkait dengan hal tersebut sesuai dengan pernyataan Pusdiklat Administrasi Kementerian Agama RI ${ }^{3}$, maka pengelola keuangan Negara mulai dari Kuasa Pengguna Anggaran, Pejabat Pembuat Komitmen sampai dengan juru bayar harus memahami aturan mengenai mekanisme dan teknis pelaksanaan anggaran, tata cara pengajuan pembayaran, tata cara

3 MODUL PENATAUSAHAAN PERBENDAHARAAN MADRASAH (PENGELOLAAN KEUANGAN PENDIDIKAN/MADRASAH), 2018. 
pelaporan, tata cara penghitungan pajak, tata cara pengadaan barang dan jasa, serta tata cara pertanggung jawaban keuangan.

Pengelola keuangan pendidikan juga dituntut dalam memberikan transparasi dan akuntabilitas ${ }^{4}$ keuangannya yang harus dipublikasikan kepada masyarakat. Demikian halnya juga dalam memutuskan besaran biaya pendidikan ditengah pandemi ini, pengelola pendidikan harus tetap mengkomunikasikannya kepada orang tua wali murid dan stakeholder lainnya pada lembaga pendidikannya tersebut. Oleh sebab itu diperlukan sebuah manajemen yang bisa menyelaraskan antaran kegiatan yang bersifat offline (manual) dan online (otomatis).

Tulisan ini akan menyoroti bagaimana sistem aplikasi online manajemen keuangan pendidikan pada lembaga pendidikan Islam negeri sebagai upaya dalam mencegah penyebaran wabah Covid-19 melalui WFH. Berbeda dengan tulisan-tulisan lain sebelumnya yang membahas mengenai keuangan pendidikan atau pembiayaan pendidikan. Misalnya tulisan Abidin $(2017)^{5}$ yang berjudul Manajemen Pembiayaan Pendidikan Tinggi Dalam Upaya Peningkatan Mutu (Studi Kasus Pada Perguruan Tinggi Swasta Menengah di Surabaya), menyatakan bahwa manajemen pembiayaan pendidikan sebagai salah satu faktor dalam peningkatan mutu, dikarenakan jika manajemen pembiayaan transparan dan akuntabel, maka akan timbul adanya kepercayaan dari para stakeholder pendidikan dan hal ini akan menjadi motivasi dari para civitas akademika dalam melaksanakan Tri Dharma PT pada PT swasta menengah di Surabaya dalam melakukan peningkatan mutu pada bidangnya masing-masing. Selanjutnya tulisan Komariah $(2018)^{6}$ berjudul konsep manajemen keuangan pendidikan menyatakan bahwa sisi otonomi menjadi peluang pada satuan pendidikan dalam mengelola sekolah, baik pada aspek dalam mengembangkan kurikulum atau pada pendanaan, namun pada sisi lain akan menjadi ancaman jika tidak SDM dan pembiyaannya tidak siap, oleh sebab itu kompetensi kepala sekolahnya mutlak diperlukan sehingga guru ataupun karyawan dapat menyelenggarakan pendidikannya dengan berkualitas. Penelitian Hermawan (2020) dengan judul Manajemen Pembiayaan

4 Undang-Undang Republik Indonesia Nomor 20 Tahun 2003 tentang Sistem Pendidikan Nasional, 2003.

5 Achmad Anwar Abidin, "MANAJEMEN PEMBIAYAAN PENDIDIKAN TINGGI DALAM UPAYA PENINGKATAN MUTU (Studi Kasus Pada Perguruan Tinggi Swasta Menengah di Surabaya)," Jurnal Penjaminan Mutu 3, no. 1 (2017): 87-99.

${ }^{6}$ Nur Komariah, "KONSEP MANAJEMEN KEUANGAN PENDIDIKAN,” Jurnal Al-Afkar 6, no. 1 (2018): 67-94. 
Pendidikan Sekolah Dasar Berbasis Aplikasi Keuangan: Studi Kasus di Sekolah Dasar Islam Terpadu Tahfidz Quran Al-Jabar Karawang. Penelitianny ini berdasarkan penggunaan aplikasi dalam keuangan pendidikan yang terkait dengan bugeting, accounting dan auditing.

Pada tulisan ini, persamaan dengan tulisan-tulisan atau penelitian terdahulu terletak pada persamaan teori umum saja yang terkait dengan keuangan atau pembiayaan pendidikan. Sedangkan perbedaannya adalah penulis menyoroti bagaimana sistem aplikasi manajemen keuangan DIPA pada lembaga pendidikan islam negeri di tengah pandemi Covid-19 sebagai upaya bekerja dari rumah (WFH). Sedangkan resech problem penelitian ini adalah; perubahan pradigma pengelolaan keuangan DIPA dan bagaiman system yng dijalankan. Kedua, Sistem yang digunakan untuk memastikan transparansi pelaporan keuangan.

\section{Manajemen Keuangan Pendidikan}

Manajemen keuangan pada dasarnya mempunyai dua dasar kata yakni "manajemen" dan "keuangan". Kata manajemen (management) mempunyai beberapa arti, tergantung pada kontek penggunaannnya. Sesuai dengan prinsip manajemen pendidikan $^{7}$ pada umumnya, kegiatan pada manajemen keuangan dilakukan melalui proses perencanaan, pengorganisasian, pengarahan, pengkoordinasian dan pengawasan/pengendalian. Sedangkan menurut Depdiknas (2007) dalam Manggar ${ }^{8}$, pengelolaan keuangan dapat diartikan sebagai tindakan dalam pengurusan (ketatausahaan) keuangan yang meliputi pencatatan, perencanaan, pelaksanaan, pertanggungjawaban, dan pelaporan.

Membahas mengenai manajemen keuangan pendidikan, terlebih dahulu membahas mengenai adanya kaitan antara kualitas pendidikan dengan manajemen keuangan. Beberapa penelitian misalnya mengungkapkan bahwa pendidikan yang berkualitas dengan aspek pembiayaan mempunyai pengaruh yang positif. Pengaruh antara pembiayaan dengan kualitas pendidikan yang bermutu jelasnya saling terkait.

7 Johannes Manggar, Yuli Cahyono, dan Medira Ferayanti, PENGELOLAAN KEUANGAN SEKOLAH/ MADRASAH (Depok: LPPKS, 2013), 4.

${ }^{8}$ Ibid. 
Penelitian Azhari ${ }^{9}$ misalnya menunjukan bahwa, pengaruh manajemen keuangan atau pembiayaan dalam pendidikan serta fasilitas pembelajaran terhadap mutu sekolah secara bersama-sama dapat memberikan pengaruh yang kuat dan signifikan.

Menurut $\operatorname{Bastian}^{10}$ dalam pelaksanaanya, pembiayaan harus didasarkan pada tingkat kualitas tertentu. Banyak faktor yang bisa dilakukan untuk meningkatkan kualitas pendidikan. Jadi biaya bukanlah salah satu jawaban yang harus ditentukan lebih awal. Namun biaya menjadi penyempurnaan syarat yang harus dipenuhi penyelenggaraan pendidikan. Dalam hal perlu diupayakan oleh para pengelola pendidikan untuk menunjukan langkah efisiensi yang dilakukan serta akuntabilitas dalam pengelolaan dana. Sebab tanpa didukung langkah efisiensi dan akuntabilitas dalam pengelolaan dana, berapa pun dana yang dikeluarkan, aktivitas yang dilakukan lembaga tidak akan berhasil meningkatkan kualitas pendidikan. Oleh karena itu, pengelola pendidikan dituntut untuk melakukan efisiensi dan akuntabilitas.

Menurut Arikunto dan Yuliana dalam Arianti ${ }^{11}$ manajemen keuangan secara umum adalah kegiatan pembiayaan meliputi tiga hal, yakni budgeting (penyusunan anggaran), accounting (pembukuan) dan auditing (pemeriksaan). Sama dengan pendapat tersebut, Thomas $\mathrm{H}$ Jones dalam buku Manajemen Pendidikan ${ }^{12}$ juga mengurai kegiatan keuangan dengan tiga tahap; tahap perencanaan keuangan (budgeting), tahap pelaksanaan (accounting) dan tahap penilaian (auditing).

Sementara itu, komponen utama manajemen keuangan meliputi: (1) Prosedur anggaran; (2) Prosedur akuntansi keuangan; (3) Pembelanjaan, pergudangan dan prosedur pendistribusian; (4) Prosedur investasi; serta (5) Prosedur pemeriksaan. ${ }^{13}$

Menurut Suad Husnan ${ }^{14}$ manajemen keuangan adalah manajemen terhadap fungsi-fungsi keuangan. Sedangkan fungsi keuangan merupakan kegiatan utama yang

\footnotetext{
${ }^{9}$ Ulpha Lisni Azhari dan Dedy Achmad Kurniady, "Manajemen Pembiayaan Pendidikan, Fasilitas Pembelajaran, Dan Mutu Sekolah," Manajemen Pembiayaan Pendidikan, Fasilitas Pembelajaran, Dan Mutu Sekolah 23, no. 2 (2016): 26-36.

${ }^{10}$ Indra Bastian, Akuntansi Pendidikan (Jakarta: Erlangga, 2006), 192.

11 Dewi Arianti, "PENERAPAN MANAJEMEN KEUANGAN PENDIDIKAN di MAN INSAN CENDEKIA SERPONG” (UNIVERSITAS ISLAM NEGERI (UIN) SYARIF HIDAYATULLAH, 2014), 28.

12 Tim Dosen Administrasi Pendidikan UPI, Manajemen Pendidikan, 1 ed. (Bandung: Alfabeta, 2008), 257.

13 E. Mulyasa, Manajemen Berbasis Sekolah: Konsep, Strategi, dan Implementasi (Bandung: PT. Remaja Rosdakarya, 2002), 42.

${ }^{14}$ UPI, Manajemen Pendidikan, 256.
} 
harus dilakukan oleh mereka yang bertanggungjawab dalam bidang tertentu. Fungsi manajemen keuangan adalah menggunakan dana dan mendapatkan dana.

Uang atau dana pada pendidikan merupakan sumber daya yang berperan penting dalam terselenggaranya proses pendidikan pada satuan pendidikan, baik pada jenjan pendidikan maupun pada jenis pendidikannya. Mengingat pentingnya hal ini, maka uang yang ada pada sebuah lembaga pendidikan haruslah dikelola dengan sebaik mungkin melalui pola-pola manajemen keuangan yang sesuai dengan prinsip-prinsip serta standar akuntansi. Apalagi pada masa pandemi Covid-19 ini, maka pengelola keuangan benar-benar dituntut memahami pola dan prinsip manajemen keuangannya.

Di lembaga pendidikan negeri, uang atau dana pendidikan tertuang pada DIPA yang dikeluarkan oleh Kementerian Keuangan. Mekanisme pengelolaan DIPA-nya pun telah di atur langsung oleh Kementerian Agama di bawah DJPB. Dalam hal budgeting misalnya, pengusulan anggaran pada lembaga pendidikan menggunakan aplikasi RKAK/L yang pada masa pandemi diganti dengan aplikasi SAKTI (Sistem Aplikasi Terintegrasi) yang prosesnya terkait dengan pengelolaan APBN dimulai dari proses penganggaran, pelaksanaan, dan pelaporan pada BUN dan Kementerian Negara/Lembaga serta terintegrasi dengan DIPA Satuan Kerja (Satker) masing-masing. Begitu juga pada hal accountingnya, menggunakan aplikasi SAS untuk pengusulan SPM, GPP sebagai database pegawai, Persediaan dan Simak BMN untuk pencatatan Barang Milik Negara (BMN), sementara untuk auditingnya menggunakan aplikasi SAIBA (Sistem Aplikasi Akuntansi Instansi Berbasis Akrual) untuk melakukan rekonsiliasi data antara Satker pada aplikasi rekonsiliasi dan penyusunan laporan keuangan berbasis web (e-Rekon\&LK).

Keseluruhan manajemen keuangan pada lembaga pendidikan negeri tersebut telah berbasis aplikasi. Pengajuan SPM di masa pandemi ini sendiri menggunakan eSPM yang dapat di akses pada laman https://espm.kemenkeu.go.id/login. Sedangkan pada laporan rekonsiliasi (penyamaan) data antara satker pendidikan dengan KPPN menggunakan e-Rekon yang dapat di akses pada laman https://e-rekonlk.kemenkeu.go.id/login. Maksud dari dilakukannya pengajuan dan laporan secara online ini adalah agar para pengelola keuangan pada Satker Pendidikan tidak berinteraksi langsung oleh petugas yang ada pada KPPN sebagai penerima SPM. 


\section{Prinsip-prinsip Manajemen Keuangan}

Dalam prakteknya, manajemen (pengelolaan) keuangan adalah tindakan yang diambil dalam rangka menjaga kesehatan keuangan pada sebuah organisasi/lembaga. Oleh sebab itu, dalam membangun sistem pada sebuah manajemen keuangan yang baik, maka kita perlu mengidentifikasi prinsip-prinsip manajemen keuangan yang baik.

Menurut Horngren (1993) dalam Imron ${ }^{15}$ ada tujuh prinsip dari manajemen keuangan yang harus diperhatikan, (1) Standar Akuntansi (Accounting Standards) dalam pengelolaan keuangan pada organisasi harus sesuai dengan prinsip dan standar akuntansi yang berlaku secara umum. Artinya, setiap akuntan di seluruh dunia dapat memahami sistem yang digunakan pada organisasi; (2) Konsistensi (Consistency) yakni sistem serta kebijakan keuangan pada sebuah organisasi harus konsisten waktu ke waktu. Pendekatan yang tidak konsisten terhadap pengelolaan keuangan merupakan suatu tanda bahwa terdapat manipulasi pada pengelolaan keuangan. Namun bukan berarti bahwa sistem pengelolaan keuangan tidak boleh disesuaikan (conditional) apabila terjadi perubahan pada organisasi; (3) Transparansi (Transparency) artinya harus terbuka terkait dengan kinerjanya, dengan menyediakan informasi yang berkaitan dengan rencana dan aktivitasnya kepada para pemangku kepentingan. Termasuk di dalamnya, menyiapkan laporan keuangan yang lengkap dan tepat waktu, akurat serta dapat dengan mudah diakses oleh pemangku kepentingan dan penerima manfaat. (4) Akuntabilitas (Accountability) yakni kewajiban moral atau hukum yang melekat pada individu, kelompok atau organisasi pengelola keuangan untuk menjelaskan bagaimana dana, peralatan atau kewenangan yang diberikan pihak ketiga telah digunakan. Semua pemangku kepentingan berhak untuk mengetahui bagaimana dana dan kewenangan digunakan. Organisasi harus dapat menjelaskan bagaimana dia menggunakan sumberdayanya dan apa yang telah dicapai sebagai pertanggungjawaban kepada pemangku kepentingan dan penerima manfaat; (5) Kelangsungan Hidup (Viability) merupakan suatu ukuran tingkat keamanan dan keberlanjutan keuangan organisasi. Agar keuangan terjaga, pengeluaran organisasi di tingkat stratejik maupun operasional harus sejalan atau disesuaikan dengan dana yang diterima. Manager dalam hal ini harus menyiapkan sebuah rencana keuangan yang menunjukan bagaimana manajemen

\footnotetext{
${ }^{15}$ Moh. Jamaluddin Imron, "MANAJEMEN PEMBIAYAAN SEKOLAH,” Al-Ibrah 1, no. 1 (2016): 69-93.
} 
keuangan di dalamnya dapat melaksanakan rencana stratejiknya dan memenuhi kebutuhan keuangannyanya. (6) Integritas (Integrity) individu yang terlibat di dalam pengelolaan keuangan harus mempunyai integritas yang baik. Selain itu, laporan dan catatan keuangan juga harus dijaga integritasnya melalui kelengkapan serta keakuratan pencatatan keuangan. (7) Pengelolaan (Stewardship) dalam manajemen keuangan harus dapat mengelola keuangannya dengan baik. Harus menjamin bahwa dana tersebut digunakan untuk mencapai tujuan yang telah ditetapkan, berhati-hati dalam perencanaan stratejik, identifikasi resiko-resiko keuangan dan membuat sistem pengendalian serta sistem keuangan yang sesuai dengan organisasi.

Dalam UU RI Nomor 1 Tahun $2004^{16}$ prinsip pengelolaan keuangan pada dasarnya harus transparan dan akuntabel. Telah dijelaskan juga pada pembahasan sebelumnya, bahwa pengelolaan keuangan pendidikan sendiri perlu memperhatikan beberapa prinsip, yakni pada UU Nomor 20 Tahun 2003 pasal 48 menyatakan bahwa, pengelolaan keuangan pendidikan didasarkan pada prinsip keadilan, efisiensi, transparansi dan akuntabilitas publik.

Sedangkan Manggar ${ }^{17}$ menyebutkan ada empat prinsip pengelolaan keuangan yakni; (1) Transparansi. Transparan artinya ada keterbukaan. Transparan di bidang pengelolaan keuangan berarti adanya keterbukaan dalam mengelola suatu kegiatan. Pada lembaga pendidikan, pengelolaan keuangan yang transparan artinya adanya keterbukaan dalam pengelolaan keuangan lembaga pendidikan, yakni keterbukaan sumber keuangan dan jumlahnya, rincian penggunaan dan pertanggungjawabannya yang jelas sehingga memudahkan pihak-pihak yang berkepentingan untuk mengetahuinya. Transparansi keuangan sangat diperlukan dalam rangka meningkatkan dukungan orangtua, masyarakat, dan pemerintah dalam penyelenggaraan seluruh program pendidikan di sekolah. Adanya transparansi dapat menciptakan kepercayaan timbal balik antara pemerintah, masyarakat, orang tua siswa dan warga sekolah melalui penyediaan informasi dan menjamin kemudahan dalam memperoleh informasi yang akurat dan memadai. Beberapa informasi keuangan yang boleh diketahui oleh semua warga sekolah dan orang tua siswa, misalnya rencana kerja anggaran sekolah/madrasah

\footnotetext{
${ }^{16}$ UNDANG-UNDANG REPUBLIK INDONESIA NOMOR 1 TAHUN 2004 TENTANG PERBENDAHARAAN NEGARA, 2004.

${ }^{17}$ Manggar, Cahyono, dan Ferayanti, PENGELOLAAN KEUANGAN SEKOLAH/MADRASAH, 5-7.
} 
(RKAS-M),sehingga bisa ditempel di papan pengumuman, di ruang guru, atau di depan ruang tata usaha. Dengan demikian, siapa pun yang membutuhkan informasi tersebut dapat mendapatkannya dengan mudah. Orang tua siswa bisa mengetahui jumlah uang yang diterima dari orang tua siswa dan pemanfaatannya oleh sekolah. Perolehan informasi ini menambah kepercayaan orang tua siswa terhadap sekolah. (2) Akuntabilitas. Akuntabilitas adalah penilai terhadap performa kerja sebagai tanggungjawab dalam pekerjaan. Akuntabilitas pengelolaan keuangan pendidikan artinya penggunaan uang sekolah sehingga dapat dipertanggungjawabkan sesuai dengan perencanaan yang telah ditetapkan sebelumnya. Agar terbangunnya akuntabilitas, maka ada beberapa hal yang perlu diperhatikan, yaitu adanya [1] transparansi para penyelenggara pengelola pendidikan dengan menerima masukan dan mengikutsertakan berbagai komponen di dalamnya, [2] memiliki standar kinerja di lembaga yang dapat diukur, dan [3] partisipasi untuk saling menciptakan suasana kondusif dalam pelayanan masyarakat dengan prosedur yang mudah, biaya yang murah, dan pelayanan yang cepat. (3) Keefektifan. Efektif artinya tercapainya tujuan yang telah ditetapkan sebelumnya. Efektifitas tidak saja pada tercapainya tujuan, namun harus ada kesesuaian kualitas hasil dengan visi. Pengelolaan keuangan dikatakan efektif jika kegiatan dapat mengatur dan membiayai aktivitas dalam mencapai tujuan lembaga dan kualitas outcomes-nya sesuai dengan rencana yang telah ditetapkan. (4) Efisiensi. Efisiensi adalah adanya nilai kuantitas pada hasil. Efisiensi merupakan perbandingan masukan (input) dengan keluaran (output), antara daya dan hasil. Daya tersebut meliputi tenaga, pikiran, waktu serta biaya.

Prinsip pengelolaan keuangan di masa pandemi Covid-19 ini sendiri cukup berbeda. Menurut Menteri Keuangan ${ }^{18}$, program penanganan Covid-19 serta pemulihan ekonomi adalah program yang luar biasa penting, didesain dalam suasana kegentingan yang memaksa. Prinsip Emergency atau urgency juga menjadi sangat penting dalam mengambil kebijakan dalam pengelolaan keuangan pemerintah. Presiden sendiri menekankan prinsip kecepatan menjadi sesuatu yang sangat penting namun pada saat

\footnotetext{
${ }^{18}$ Rahayu Puspasari, "Rakernas Akuntansi dan Pelaporan Keuangan Pemerintah 2020: Mewujudkan Akuntabilitas dalam Penanganan Pandemi Covid-19 dan Pemulihan Ekonomi Nasional," https://www.kemenkeu.go.id/, last modified 2020, https://www.kemenkeu.go.id/publikasi/siaranpers/siaran-pers-rakernas-akuntansi-dan-pelaporan-keuangan-pemerintah-2020-mewujudkanakuntabilitas-dalam-penanganan-pandemi-covid-19-dan-pemulihan-ekonomi-nasional/.
} 
yang sama ditekankan bahwa kecepatan tidak boleh mengompromikan akuntabilitas transparansi dan pengelolaan yang baik.

Terkait dengan prinsip Horngren (1993) yang dijelaskan sebelumnya, prinsip konsisten dalam manajemen keuangan bukan berarti tidak boleh disesuaikan (conditional) apabila terjadi perubahan pada organisasi, apalagi dalam hal ini terjadi pada masa pandemi. Prinsip Emergency berlaku dalam hal ini dengan mengkondisikan sesuai keadaan saat ini. Prinsip pengelolaan keuangan di masa pandemi ini akhirnya menggunakan sistem online pada beberapa kegiatan dalam pengelolaan aplikasi keuangannya. Upaya ini juga dalam mewujudkan daya yang meliputi tenaga, pikiran, waktu dan biaya para pengelola keuangan pada Satker pendidikan.

\section{Aplikasi Pengelolaan Keuangan Pendidikan}

Aplikasi yang digunakan dalam pengelolaan keuangan DIPA pendidikan adalah antara lain: (1) Aplikasi RKAK/L. Aplikasi RKAKL merupakan sebuah alat (tool) untuk mempermudah kerja dalam menyusun Rencana Kegiatan dan Anggaran Kementerian / Lembaga (RKAKL). (2) Aplikasi POK. Aplikasi POK ini berguna untuk memberikan kemudahan dalam pembuatan laporan-laporan kegiatan operasional. (3) Aplikasi SAS. Sistem Aplikasi Satker yang selanjutnya disebut Aplikasi SAS adalah aplikasi berbasis desktop yang digunakan sebagai sarana untuk membuat Data Kontrak, RPD Harian, SPM, LPJ Bendahara bagi Satker. Pada Satker pendidikan SPM gaji guru dan pegawai, SPM dana sertifikasi guru, honorarium kegiatan, dana BOS, dana rutin dan sebagainya. (4) Aplikasi PIN PPSPM. Personal Identification Number (PIN) PPSPM adalah Tanda Tangan Elektronik Pejabat Penanda Tangan SPM (PPSPM) yang berisi sederet angka yang diverifikasi autentikasinya (keasliannya) oleh sistem pada KPPN. Tanda Tangan Elektronik digunakan sebagai alat verifikasi dan autentikasi sebagaimana dimaksud dalam Undang Undang Informasi dan Transaksi Elektronik. PIN PPSPM yang dapat diterima aplikasi Surat Perintah Pembayaran Dana (SP2D) KPPN merupakan bentuk pernyataan bahwa SPM adalah benar telah diterbitkan dan ditandatangani oleh PPSPM satker bersangkutan. (5) Aplikasi GPP. Aplikasi GPP digunakan untuk mempermudah mengelolah gaji PNS pusat pada Satker. Aplikasi GPP adalah administrasi belanja pegawai yang lebih mudah dengan akurasi yang tinggi serta lebih efisien tenaga dan waktu. (6) Aplikasi SIMAK BMN. Aplikasi SIMAK-BMN 
(Sistem Informasi Manajemen dan Akuntansi Barang Milik Negara) adalah aplikasi yang digunakan untuk mencatat dan mengorganisir barang milik Negara, mulai dari pembelian, transfer masuk-keluar antar instansi, sampai penghapusan dan pemusnahan barang milik Negara. (7) Aplikasi Persediaan. Aplikasi Persediaan adalah Sistem aplikasi yang diperuntukan bagi Unit Akuntansi Kuasa Pengguna Anggaran (KPA), dengan tujuan memberikan kemudahan pengelolaan Stok barang persediaan untuk keperluan operasional kantor. (8) Aplikasi SAIBA. Dahulu dinamakan SAI dan berubah menjadi Aplikasi SAIBA yang merupakan terobosan aplikasi akuntansi berbasis akrual yang diharapkan memenuhi kebutuhan informasi laporan keuangan yang disyaratkan oleh Standar Akuntansi Pemerintahan (SAP). (9) Aplikasi OM SPAN. Aplikasi Online Monitoring Sistem Perbendaharaan dan Anggaran Negara (Aplikasi OM-SPAN) adalah aplikasi yang digunakan dalam rangka memantau transaksi dalam Sistem Perbendaharaan dan Anggaran Negara (SPAN) dan menyajikan informasi sesuai kebutuhan yang diakses melalui jaringan berbasis web. OM-SPAN dibuat dalam rangka memberikan layanan informasi yang cepat, akurat, terinci, dan terintegrasi mengenai implementasi SPAN.

Pada masa pandemi Covid-19 sebagai upaya dalam menerapkan protokol kesehatan, maka melalui Ditjen Perbendaharaan Kementerian Keuangan RI di bawah Direktorat Sistem Informasi dan Teknologi Perbendaharaan Negara, di launchinglah aplikasi pengajuan SPM dalam bentuk eltronik atau online. Berikut beberapa aplikasinya, (1) Aplikasi e-SPM. Untuk mengatasi efisiensi waktu dan tenaga bagi beberapa satker dalam mengantarkan dokumen SPM secara langsung kepada KPPN, telah mengembangkan sistem Aplikasi e-SPM. Aplikasi e-SPM merupakan sistem penyampaian ADK dan dokumen melalui jaringan internet dan tanpa tatap muka. (2) Aplikasi e-Rekon. E-Rekon dan LK adalah aplikasi berbasis web yang dikembangkan dalam rangka proses rekonsiliasi (penyamaan) data transaksi keuangan dan penyusunan Laporan Keuangan Kementerian Negara/Lembaga.

\section{Aplikasi Online; Upaya Pencegahan Pandemi Covid-19}

Tidak dapat dipungkiri bahwa pengaruh munculnya dan menyebarnya wabah Covid-19 amat memengaruhi seluruh aspek kehidupan, tidak terkecuali dunia pendidikan. Keadaan ini akhirnya memancing respon para pemangku kepentingan dan 
pemangku kebijakan dunia pendidikan dengan mengubah proses serta prosedur kegiatan di dalam pendidikan. Semua kegiatan di dalam pendidikan dilakukan dalam jaringan (daring). Di sisi yang lain, lembaga pendidikan kitapun dituntut untuk dapat memberikan pelayanan standar kesehatan melalui WFH, Pembatasan Sosial Skala Besar (PSBB) dan juga penerapan New Normal Era.

Lalu pertanyaannya adalah bagaimana ketentuan pengajuan SPM ke KPPN dalam masa darurat Covid-19 ini. Selama masa darurat Covid ini, Kantor Wilayah Direktoran Jenderal Perbendaharaan (DJPb) dan KPPN tetap memberikan pelayanan perbendaharaan dengan mempertimbangkan protokol kesehatan penanganan Covid-19 sampai ada penetapan kondisi lebih lanjut.

Untuk layanan pengajuan SPM ke KPPN sekarang menggunakan aplikasi eSPM yang dapat diakses menggunakan internet. Terdapat beberapa ketentuan tentang pengajuan SPM oleh satuan kerja kepada KPPN untuk mencairkan alokasi dananya yang bersumber dari APBN. Ketentuan ini berlaku selama periode masa darurat Covid19 yang ditetapkan pemerintah melalui $\mathrm{DJPb}$ Kemenkeu ${ }^{19}$, yakni antara lain: (1) Mengutamakan pengajuan SPM yang sifatnya PRIORITAS; (2) Pembayaran tagihan dalam rangka penanganan darurat Covid-19; (3) Pembayaran belanja pegawai dan penghasilan PPNPN; (4) Pembayaran belanja bantuan pemerintah dan bantuan sosial; Pembayaran belanja mendesak lainnya; (5) Pengajuan SPM GUP dilaksanakan dengan ketentuan: a) Satker agar mengajukan SPM GUP Tunai dan SPM GUP KKP satu kali dalam satu bulan, b) Melakukan simplikasi pengajuan GUP, yaitu satu SPM GUP Tunai agar memuat bebrapa kegiatan, output, dan lokasi yang berbeda sepanjang dalam jenis belanja yang sama sebagaimana diatur dalam perdirjen perbendaharaan nomor PER-6/PB/2018 tentang tata cara penggabungan beberapa kegiatan, output, dan lokasi dalam penerbitan SPM GUP, PTUP, dan SPM LS kepada bendahara pengeluaran, c) Pengajuan SPM TUP Tunai dan SPM TUP KKP hanya untuk keperluan yang bersifat prioritas dan mendesak berdasarkan pertimbangan kepala KPPN, d) Waktu pengajuan SPM ke KPPN diatur dengan ketentuan, waktu penerimaan SPM secara elektronik adalah mulai pukul 07.30 s.d. 12.00 waktu setempat. (6) Kepala Kanwil DJPb

19 "BAGAIMANA KETENTUAN PENGAJUAN SPM KE KPPN DALAM MASA DARURAT COVID-19?," https://djpb.kemenkeu.go.id/, last modified 2020, https://djpb.kemenkeu.go.id/kppn/tarakan/id/data-publikasi/berita-terbaru/2830-bagaimana-ketentuanpengajuan-spm-ke-kppn-dalam-masa-darurat-Covid-19.html. 
menetapkan jumlah maksimal dokumen SPM dalam satu hari layanan yang dapat diterima oleh KPPN dalam wilayah kerjanya. Ketentuan mengenai sanksi terhadap keterlambatan penyelesaian tagihan dalam 17 hari kerja dan keterlambatan penyampaian data kontrak termasuk addendum kontrak dinyatakan tidak berlaku

Itulah beberapa ketentuan mengenai pengajuan SPM ke KPPN dalam masa darurat Covid-19 oleh pemerintah pusat.

Untuk meminimalkan penyebaran Covid-19 para pengguna layanan dipersilahkan menggunakan fasilitas layanan non tatap muka seperti melalui telepon, email, whatsapp dan saluran komunikasi lain. Dalam hal satuan kerja tetap memerlukan layanan secara tatap muka agar bersama menerapkan protocol social distance seperti menjaga jarak aman, mengenakan masker, menghindari kontak fisik dan kerumunan, serta terus menjaga sanitasi diri dan memanfaatkan sarana sanitasi yang tersedia.

Pada kondisi pandemi Covid-19 menuntut adanya penyesuaian dalam mekanisme pencairan maupun pengalokasiannya. Upaya penyerapan dana oleh satkersatker melalui pengajuan SPM diusahakan seoptimal mungkin. Ada beberapa perubahan terkait pencairan dana yang dilakukan oleh KPPN. Misalnya pada KPPN Tanjung Pinang yang menerapkan Tatanan Normal Baru (New Normal) di lingkungan wilayah kerjanya, sebagai berikut: (1) Mengutamakan pengajuan SPM yang sifatnya prioritas, seperti pembayaran tagihan dalam rangka penanganan keadaan darurat COVID-19, pembayaran belanja pegawai dan penghasilan PPNPN (Pegawai Pemerintah Non Pegawai Negeri), pembayaran belanja bantuan pemerintah dan bantuan sosial, pembayaran belanja mendesak lainnya; (2) Satker agar mengajukan SPM-GUP Tunai dan SPM GUP-KKP satu kali dalam satu bulan, jika lebih dari satu kali maka diperlukan surat persetujuan dari Kepala KPPN; (3) Pengajuan SPM TUP Tunai dan SPM TUP KKP hanya untuk keperluan yang bersifat prioritas dan mendesak berdasarkan pertimbangan Kepala KPPN; (4) Waktu penerimaan SPM secara elektronik mulai pukul 08.00 s.d pukul 12.00 waktu setempat ; (5) Sanksi terhadap keterlambatan penyelesaian tagihan dalam 17 hari kerja dan keterlambatan penyampaian data kontrak termasuk addendum kontrak dinyatakan tidak berlaku.

Panduan yang harus dipedomani di masa new normal, KPPN Tanjung Pinang menerapkan beberapa peraturan, yakni: (1) mengikuti prosedur pencegahan tertular Covid-19 dengan mencuci tangan dan memakai masker; (2) melakukan jaga jarak 
(physical/social distancing); (3) mengadakan pola kerja dari rumah (work from home/WFH); (4) pelayanan kepada satker secara tatap muka ditiadakan; (5) pelayanan Surat Perintah Membayar (SPM), Surat Keterangan Penghentian Pembayaran (SKPP), koreksi SPM dan setoran penerimaan Negara, penatausahaan rekening satker, penatausahaan surat masuk/keluar, dan layanan lainnya, dilakukan secara elektronik. Adapun berkas fisik yang harus diserahkan ke KPPN oleh petugas satuan kerja maupun kurir, harus melalui protokol kesehatan berupa pengecekan suhu badan dengan thermogun, memberikan cairan disinfektan untuk digunakan di telapak tangan, dan antri sesuai dengan tanda panduan di ruang layanan; (6) pengiriman berkas secara elektronik dari satker ke KPPN Tanjung Pinang melalui e-SPM bisa dilakukan pada pukul 08.00 s.d 12.00 WIB (jam kerja); (7) sebagian pegawai tetap melakukan pekerjaan di kantor (work at office/WAO) untuk tetap memenuhi Bussines Core Process (BCP).

Sedangkan KPPN Bandar Lampung ${ }^{20}$ mengeluarkan kebijakan dalam hal penyampaian Surat Perintah Membayar (SPM) melalui sarana elektronik yaitu dengan dirilisnya aplikasi e-SPM. KPPN Bandar Lampung menerbitkan aturan dalam penyampaian SPM dengan memproses 100 SPM per hari, setiap Satker hanya dibolehkan mengupload maksimal 3 SPM per hari, Satker mengupload berkas-berkas SPM yang terdiri dari ADK SPM, File PDF SPM, ADK Gaji, ADK Gaji PPNPN dan File CSV Rekapan SPM.

Langkah-langkah di atas merupakan upaya KPPN dan Satker Pendidikan dalam rangka mendukung optimisme "Mengawal APBN, Indonesia Maju” yang dicanangkan pemerintah.

\section{Penutup}

Dampak pandemi Corona Virus Disease 2019 (Covid-19) telah berdampak pada kehidupan, antara lain terhadap perlambatan pertumbuhan ekonomi nasional, penurunan penerimaan Negara dan peningkatan belanja Negara serta pembiayaan, sehingga diperlukan berbagai upaya Pemerintah untuk melakukan penyelamatan

\footnotetext{
${ }^{20}$ Tanggamus, "Ka TU Kemenag Tanggamus Sosialisasi SPM pada saat Darurat Pandemi Corona Covid 19," https://lampung.kemenag.go.id/, last modified 2020, https://lampung.kemenag.go.id/news-517989-.html.
} 
kesehatan dan perekonomian nasional, dengan fokus pada belanja untuk kesehatan, jaring pengaman sosial (social safety net) serta pemulihan perekonomian.

Dampak dari hal tersebut juga pada pengelolaan keuangan Negara yang mengalami perubahan kebijakannya. Di masa pandemi Covid-19 saat ini, berbagai aktivitas menjadi terhambat. Termasuk layanan pada instansi pemerintah maupun lembaga pendidikan. Dalam rangka pencegahan serta penyebaran Covid-19, beberapa lembaga pendidikan mulai menerapkan work from home (WFH) sesuai anjuran dari pemerintah.

Demikian pula dengan instansi KPPN. Sesuai dengan tugas KPPN adalah melaksanakan kewenangan perbendaharaan dan Bendahara Umum Negara (BUN), penyaluran pembiayaan atas beban anggaran, serta penatausahaan penerimaan dan pengeluaran anggaran melalui dan dari kas negara berdasarkan peraturan perundangundangan. Program pemerintah dalam rangka pencegahan dan penanggulangan pandemi Covid-19 pada layanan di KPPN dilakukan tanpa tatap muka atau jaga jarak (social distancing). Satker pendidikan sebagai mitra kerja KPPN dapat memaksimalkan aplikasi yang sudah berbasis online untuk mengakses layanan. Seperti e-SPM dan eRekon \& LK. Layanan konsultasi memanfaatkan media komunikasi seperti whatsapp, media sosial, maupun telepon kantor. Sedangkan untuk layanan bimbingan atau pun sosialisasi, dilakukan melalui sarana video conference. Khusus untuk layanan pencairan anggaran, lembaga pendidikan Negeri dapat mengakses aplikasi e-SPM. Penggunaan aplikasi e-SPM tersebut untuk menggantikan layanan pencairan anggaran melalui surat elektronik resmi satuan kerja yang telah terdaftar resmi di KPPN

Di masa pandemi ini, layanan KPPN tidak normal sebagaimana biasa. Oleh karena itu, dalam layanan penerimaan SPM diberlakukan pembatasan waktu penerimaan dan jumlah SPM yang diterima. Hal ini juga dapat menghemat biaya perjalanan dinas lembaga pendidikan Negeri. Biaya perjalanan dinas tersebut bisa dialihkan untuk keperluan yang lebih prioritas dan mendesak. Aplikasi e-SPM ini juga memudahkan satuan kerja untuk mengajukan SPM dari mana pun karena bersifat daring. 


\section{Daftar Pustaka}

Achmad Anwar Abidin. "MANAJEMEN PEMBIAYAAN PENDIDIKAN TINGGI DALAM UPAYA PENINGKATAN MUTU (Studi Kasus Pada Perguruan Tinggi

Swasta Menengah di Surabaya).” Jurnal Penjaminan Mutu 3, no. 1 (2017): 87-99. Akdon, Kurniady, Dedy Achmad, dan Deni Darmawan. Manajemen Pembiayaan Pendidikan. Diedit oleh Pipih Latifah. Bandung: Remaja Rosdakarya, 2015.

Arianti, Dewi. "PENERAPAN MANAJEMEN KEUANGAN PENDIDIKAN di MAN INSAN CENDEKIA SERPONG.” UNIVERSITAS ISLAM NEGERI (UIN) SYARIF HIDAYATULLAH, 2014.

Azhari, Ulpha Lisni, dan Dedy Achmad Kurniady. "Manajemen Pembiayaan Pendidikan, Fasilitas Pembelajaran, Dan Mutu Sekolah.” Manajemen Pembiayaan Pendidikan, Fasilitas Pembelajaran, Dan Mutu Sekolah 23, no. 2 (2016): 26-36.

Bastian, Indra. Akuntansi Pendidikan. Jakarta: Erlangga, 2006.

Imron, Moh. Jamaluddin. "MANAJEMEN PEMBIAYAAN SEKOLAH." Al-Ibrah 1, no. 1 (2016): 69-93.

Komariah, Nur. "KONSEP MANAJEMEN KEUANGAN PENDIDIKAN.” Jurnal AlAfkar 6, no. 1 (2018): 67-94.

Manggar, Johannes, Yuli Cahyono, dan Medira Ferayanti. PENGELOLAAN KEUANGAN SEKOLAH/ MADRASAH. Depok: LPPKS, 2013.

Mulyasa, E. Manajemen Berbasis Sekolah: Konsep, Strategi, dan Implementasi. Bandung: PT. Remaja Rosdakarya, 2002.

Puspasari, Rahayu. "Rakernas Akuntansi dan Pelaporan Keuangan Pemerintah 2020: Mewujudkan Akuntabilitas dalam Penanganan Pandemi Covid-19 dan Pemulihan Ekonomi Nasional." https://www.kemenkeu.go.id/. Last modified 2020. https://www.kemenkeu.go.id/publikasi/siaran-pers/siaran-pers-rakernas-akuntansidan-pelaporan-keuangan-pemerintah-2020-mewujudkan-akuntabilitas-dalampenanganan-pandemi-covid-19-dan-pemulihan-ekonomi-nasional/.

Tanggamus. "Ka TU Kemenag Tanggamus Sosialisasi SPM pada saat Darurat Pandemi Corona Covid 19." https://lampung.kemenag.go.id/. Last modified 2020. https://lampung.kemenag.go.id/news-517989-.html.

UPI, Tim Dosen Administrasi Pendidikan. Manajemen Pendidikan. 1 ed. Bandung: Alfabeta, 2008. 
"BAGAIMANA KETENTUAN PENGAJUAN SPM KE KPPN DALAM MASA DARURAT COVID-19?" https://djpb.kemenkeu.go.id/. Last modified 2020. https://djpb.kemenkeu.go.id/kppn/tarakan/id/data-publikasi/berita-terbaru/2830bagaimana-ketentuan-pengajuan-spm-ke-kppn-dalam-masa-darurat-covid-19.html. MODUL PENATAUSAHAAN PERBENDAHARAAN MADRASAH (PENGELOLAAN KEUANGAN PENDIDIKAN/MADRASAH), 2018.

Peraturan Menteri Pendidikan dan Kebudayaan (Permendikbud) Nomor 24 Tahun 2020 tentang Petunjuk Teknis Bantuan Operasional Sekolah (BOS) Afirmasi dan Bantuan Operasional Sekolah (BOS) Kinerja, dana BOS Afirmasi, 2020.

UNDANG-UNDANG REPUBLIK INDONESIA NOMOR 1 TAHUN 2004 TENTANG PERBENDAHARAAN NEGARA, 2004.

Undang-Undang Republik Indonesia Nomor 20 Tahun 2003 tentang Sistem Pendidikan Nasional, 2003. 